Article

\title{
Monitoring Retreat of Coastal Sandy Systems Using Geomatics Techniques: Somo Beach (Cantabrian Coast, Spain, 1875-2017)
}

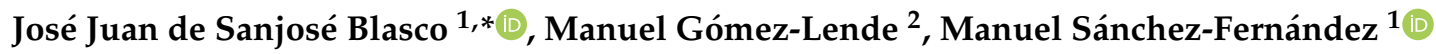 \\ and Enrique Serrano-Cañadas 2 (D) \\ 1 Departamento de Expresión gráfica, Escuela Politécnica, Universidad de Extremadura, 06006 Badajoz, Spain; \\ msf@unex.es \\ 2 Departamento de Geografía, Facultad de Filosofía y Letras, Universidad de Valladolid, \\ 47011 Valladolid, Spain; manuelglende@hotmail.com (M.G.-L.); serranoe@fyl.uva.es (E.S.-C.) \\ * Correspondence: jjblasco@unex.es; Tel.: +34-927-25-70-00 (ext. 57546)
}

Received: 31 July 2018; Accepted: 16 September 2018; Published: 19 September 2018

check for updates

\begin{abstract}
The dynamics and evolution of a coastal sandy system over the last 142 years (1875-2017) were analyzed using geomatics techniques (historical cartography, photogrammetry, topography, and terrestrial laser scanning (TLS)). The continuous beach-dune system is a very active confining sand barrier closing an estuarine system where damage is suffered by coastal infrastructures and houses. The techniques used and documentary sources involved historical cartography, digitalizing the 5-m-level curve on the maps of 1875, 1908, 1920, 1950, and 1985; photogrammetric flights of 1985, 1988, and 2001 without calibration certificates, digitalizing only the upper part of the sandy front; photogrammetric flights of 2005, 2007, 2010, and 2014, using photogrammetric restitution of the 5-m-level curve; topo-bathymetric profiles made monthly between 1988 and 1993 using a total station; a terrestrial laser scanner (TLS) since 2011 by means of two annual measurements; and the meteorological data for the period of 1985-2017. The retreat of the sandy complex was caused by winter storms with large waves and swells higher than $6 \mathrm{~m}$, coinciding with periods demonstrating a high tidal range of over 100 and periods with a large number of strong storms. The retreat was $8 \mathrm{~m}$ between December 2013 and March 2014. The overall change of the coastline between 1875 and 2017 was approximately $415 \mathrm{~m}$ of retreat at Somo Beach. The erosive processes on the foredune involved the outcrop of the rock cliff in 1999 and 2014, which became a continuous rocky cliff without sands. To know the recent coastal evolution and its consequences on the human environment, the combined geomatic techniques and future TLS data series may lead to the improvement in the knowledge of shoreline changes in the context of sea level and global changes.
\end{abstract}

Keywords: coastal geomorphology; monitoring; morphology; geomatic techniques; sandy systems

\section{Introduction}

Sandy complexes of shallow coasts are highly dynamic systems deriving from the interrelationships between marine and atmospheric agents. Their morphogenesis varies constantly and at different rhythms, and changes are, therefore, spatial and temporal, alongshore and cross-shore [1]. The multiple factors that affect the coastal dynamic have been subjected to theoretical quantitative analyses since the end of the 1960s by means of reference modeling for the study of sandy systems [1].

Several geomatics studies were conducted in recent decades on the coastal sandy system of El Puntal de Somo [1-10], and other research analyzed several of the world's beaches using diverse geomatic techniques [11-18]. In this case, the geomorphological context in which the sandy systems 
developed not only depend on their exposure to waves, astronomical tides, storm surge, run-up, winds, or fluvial runoff, but also on the energy received and the alteration or acceleration of morphogenetic processes. To these factors, their estuarine configuration must be added, forcing the consideration of tidal currents [19] and geomorphological elements such as sand bars [20], both influential on the coastal dynamic as a natural barrier against the storms of the open sea.

Human action is the most influential factor in the morphodynamics of beaches and sand strips in estuary systems on the coast of the Cantabrian Sea [21-29] and Santander Bay. The elimination of the submerged sand bar known as Las Quebrantas due to dragging in the mouth of the bay led to an increase in the effect of waves on the sand banks. The geomorphological context and human action also affect the increase or attenuation of the risk of erosion and flooding, both now and in the future [2,3], as well as the potential retreat of the shoreline.

The nature of the interphase of coastal areas, together with land use, leads to the need for knowledge in order to provide suitable territorial management in tourist and leisure areas such as the one we are dealing with here. The need to monitor, analyze, and model processes is recommended to determine suitable interventions on the coast in the present and immediate future $[5,18,19]$ in a place such as Santander Bay, which underwent great urban and socio-economic transformation.

The main aim of this study was to analyze storms in combination with geomatic observations of the beach-dune system in El Puntal de Somo, one of the largest on the Cantabrian coast [30]. The retreat of the sand bar between El Puntal and Loredo Beach was analyzed using geomatic techniques and historical maps in combination with the analysis of the influence storms had on it during the period of 1985-2017.

\section{The Study Area}

The sandy system of beaches and dunes of El Puntal in Somo, Loredo is located in the bay of Santander, one of the most important estuarine inlets of the Cantabrian coast, and has an area of $23.46 \mathrm{~km}^{2}$ and a perimeter of $97 \mathrm{~km}$. The estuary belongs to the bay of Biscay and is represented by two subsystems, the Estuary of Santander itself, a diapiric basin formed in clays and gypsum of the Triasic age (Keuper facies) with fractures in the NW-SE direction where small streams flow out (Tijero, Boo, and Solía); and the Estuary of Cubas, the fluvial valley of the Miera River with an infill of alluvial sediments $[20,31,32]$.

The exterior of the estuary is made up of a continuous beach-dune system within a confining sand barrier associated with a low coastal environment prolonged with a sand strip (Figure 1). There are two large morphosedimentary areas: the barrier strip of El Puntal-Punta Rabiosa, $\sim 3 \mathrm{~km}$ in length and protected from the waves of the open sea, and the beach of Somo-Quebrantas-Loredo, $\sim 2 \mathrm{~km}$ in length and exposed to the most active swells from the NW [1]. The barrier strip and beaches close the Santander Estuary and are boxed within the estuarine subsystem of the Cubas Estuary [33,34]. Taken as a whole, it makes up one of the most extensive sandbanks of the Cantabrian Sea with a total of 1,047,190 $\mathrm{m}^{2}$ (Puntal de Somo: $308,149 \mathrm{~m}^{2}$ and Somo-Quebrantas-Loredo dune complex: $739,041 \mathrm{~m}^{2}$ ) [30] and forms the mouth of the Miera River through the Cubas Estuary.

Both systems are the result of the divergence of the NW-dominant swell by diffraction and reflection on the Magdalena Peninsula and in the sandy bar of Las Quebrantas toward Punta Rabiosa, a sheltered area with NE exposure, and toward the beaches of Somo and Loredo, exposed beaches with $\mathrm{N}$ and NW exposure, respectively $[1,3,10,30,35]$. The evolution of the entire sandy system shows a longitudinal tendency toward the west, its apex stretching and turning toward the interior of the bay, and a layout of the whole sand bar toward concavity through its central area $[5,10,19,20]$ (Figure 1).

The mean annual height of the significant swell (Hs) is $1 \mathrm{~m}$, and $5 \mathrm{~m}$ for swells in winter storms of a NW component with peak periods of $16 \mathrm{~s}$, with short small waves in the interior of the bay of a SW component generated locally, and semi-daytime tides averaging $3 \mathrm{~m}$ and $5 \mathrm{~m}$ in spring $[7,10]$. Nevertheless, the Magdalena Peninsula implies intense variations in swell, reaching all the studied sand system [3]. 


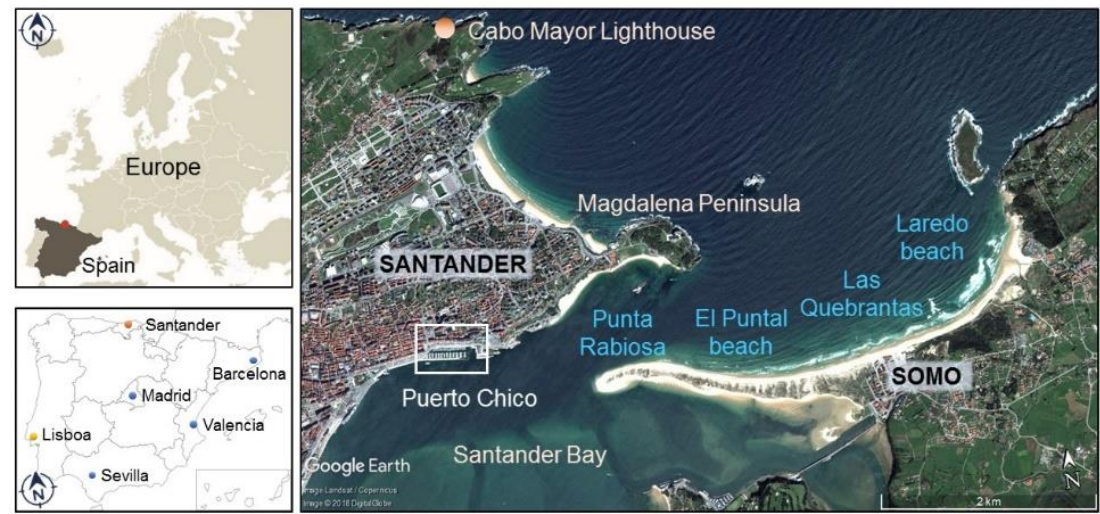

Figure 1. Geographical location of Somo Beach.

Erosion rates within annual cycles were also modeled and highlighted depending on the different protection of beaches with respect to the diffraction of the swell. In this way, the more exposed beaches have a greater erosion rate and a marked annual erosion cycle as a result of the greater frequency of erosion during the autumn months [3].

The dunes of El Puntal Beach and the Miera Estuary are sites of community importance due to their high ecological value in spite of the intense human activity deriving from urban expansion and intensive extractions, dragging, and infills of the bay since the 18 th century $[31,35,36]$. Its dune systems were also the subject of restoration programs, mainly following damage by large storms [19,37], and research into the influence of human activity on the risk of floods and erosion by the entrance of the sea shows a flood level on the beach of Loredo of $10 \mathrm{~m} \mathrm{[3].}$

\section{Methodology}

\subsection{Analysis of Historical Mapping (1726-1860)}

For the historical analysis of the dynamic of the El Puntal Beach, the first maps of the city of Santander and its surroundings can be used. These were drawn up by Isidro Próspero Verboom in 1726 (Army Geographical Service). These maps represent the barrier strip that emerges in the neap low tides (Figure 2a). Later, on the 1860 map drawn up by Francisco de Coello (National Geographic Institute), the sandy bar disappeared, and a sand barrier was generated perpendicular to the area of Las Quebrantas (Figure 2b).

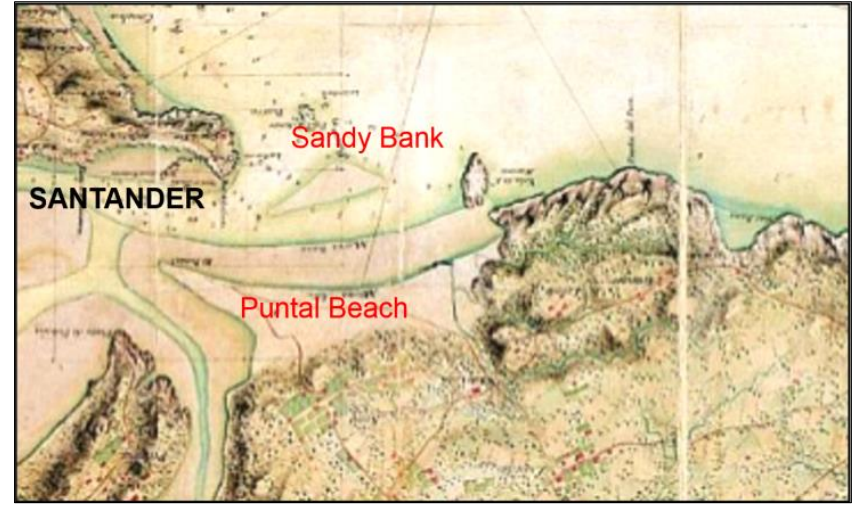

(a)

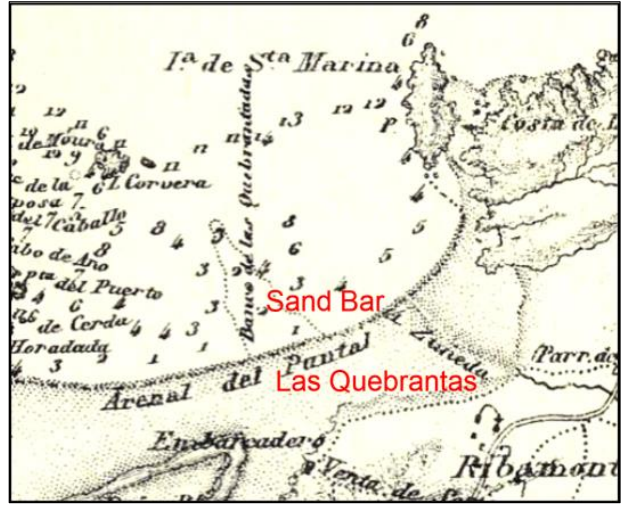

(b)

Figure 2. (a) Map of the beach of Somo by Isidro Próspero (1726) with the sandy bank; (b) map by Francisco de Coello (1860) with the sand bar. 
The maps of 1726 and 1860 were not used in a cartographical study of the evolution of the beach of El Puntal since it was not possible to georeference them, i.e., transform the map into the geodesic system of official reference in Spain (ETRS 89). As seen in Figure 2, there are no cartographic details in which ground control points can be located (crossings of paths, buildings, field fencing or walling, etc.). Despite not using these maps for the metric analysis of the evolution of Somo Beach, these historical maps give a good idea of how the coastal changes are continuous and are not due to punctual processes. The most influential factor in the retreat of the coastline at Somo Beach may possibly be large storms; thus, a detailed study was made of the last 32 years (1985-2017), since reliable information is available for this period.

\subsection{Analysis of Sea Storms (1985-2017)}

Sea storms were studied using the daily swell data of the Cabo Mayor lighthouse (4 km to the north of the beach of El Puntal) at 9:00 a.m. and 3:00 p.m. (information recorded by the State Meteorological Agency and available since 1985). Days with waves of over $5 \mathrm{~m}$ were selected, as well as those with waves of over $6 \mathrm{~m}$ (very rough seas). In addition, high tides from 1985 were scrutinized to find those with a range of over 80 , as well as those with a range of over 100.

In order to analyze the influence of sea storms on the coast, the coincidence between high tides and large swells was considered. We think that, if these two factors do not coincide in time, the retreat of the shoreline will not be as significant. Table 1 shows the number of days and number of storms (there are storms that last more than one day) distributed in five-year periods. Table 1 reveals two coincidences: swells of between $5 \mathrm{~m}$ and $6 \mathrm{~m}$ with a tidal range of over 80 (medium storms), and swells of over $6 \mathrm{~m}$ with a tidal range of over 100 (large storms).

Table 1. Number of days that coincide in time (timetable): large waves and large tidal range (high tide).

\begin{tabular}{ccc}
\hline \multirow{2}{*}{ Period } & Swell between $\mathbf{5} \mathbf{~}$ and $\mathbf{6} \mathbf{~ m}$ & Swell $>\mathbf{6} \mathbf{~ m}$ \\
\cline { 2 - 3 } & Tidal Range $>\mathbf{8 0}$ & Tidal Range $>\mathbf{1 0 0}$ \\
\hline $1985-1989$ & 2 days (2 storms) & 0 days \\
$1990-1994$ & 2 days (2 storms) & 0 days \\
$1995-1999$ & 9 days (8 storms) & 3 days (2 storms) \\
$2000-2004$ & 2 days (2 storms) & 2 days (2 storms) \\
$2005-2009$ & 3 days (2 storms) & 3 days $(2$ storms) \\
$2010-2014$ & 4 days (3 storms) & 6 days (3 storms) \\
$2015-2017$ & 0 days & 0 days \\
\hline
\end{tabular}

The information obtained from the lighthouse of Cabo Mayor was checked against the library of headlines in local newspapers, which described the rough state of the sea; in all cases, there was a coincidence between the storms recorded at the lighthouse of Cabo Mayor and the newspaper headlines. The dates taken from the records of Cabo Mayor were also checked against the statistical data of swells recorded by the Environmental Hydraulic Institute of Cantabria and against those of the swell statistics of REDCOS (Coastal Network of Swells at State Ports), which coincided in all cases with the values in Table 1 .

What follows is an analysis of the coastal dynamic, which serves to check whether any correspondence exists between storms and the beach dynamic. Although there are outside factors that may affect the dynamic of this beach, a great deal of dragging was done in the bay of Santander in the 1980s so that ships could reach the industrial port (inaugurated in 1985) and the ferry dock (inaugurated in 1989) $[38,39]$.

\subsection{Cartographical Study (1875-1985)}

For the cartographical analysis of the evolution of the beach of El Puntal, maps were available from the years of 1875, 1908, 1920, 1950, and 1985 from the Port Authority of Santander (Figure 3). 
The different cartographies used (Figure 3) were georeferenced in ETRS 89 so as to collect them all in the same system of coordinates. Only in this way could comparisons be made among maps and other geomatic techniques be used (photogrammetry, topography, and terrestrial laser scanning (TLS)). Using the global navigation satellite system (GNSS), coordinates in ETRS 89 were given to 31 elements present today (houses, churches, walls, etc.) distributed around the bay of Santander, which are represented on several of the historical maps.

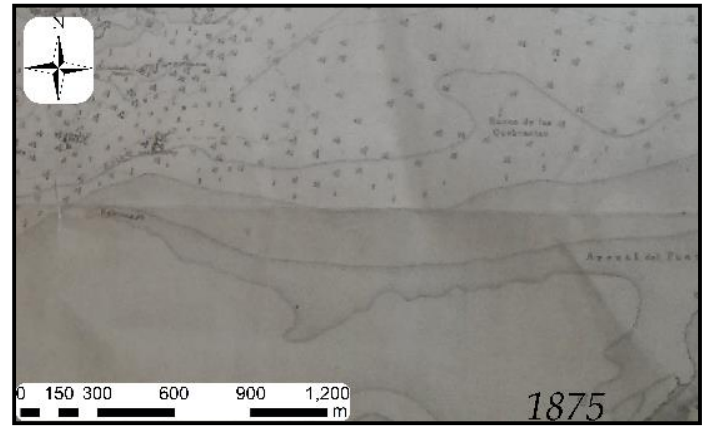

(a)

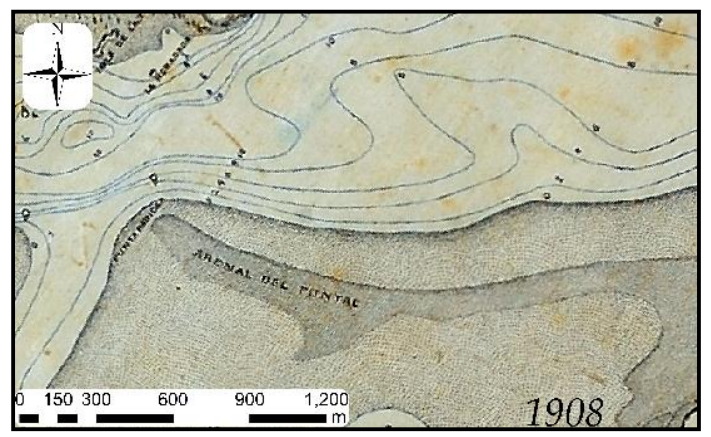

(b)

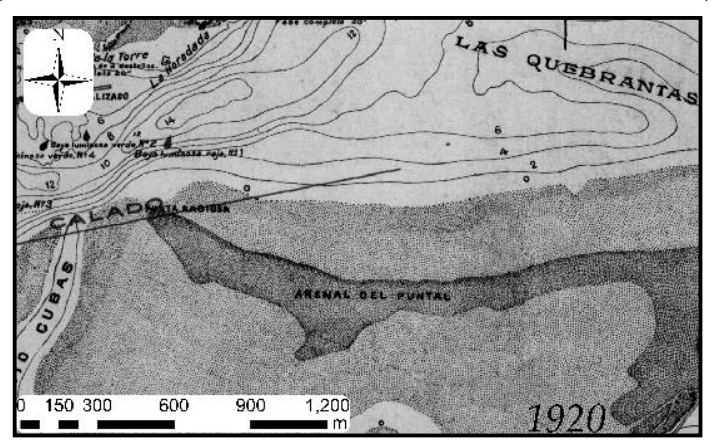

(c)

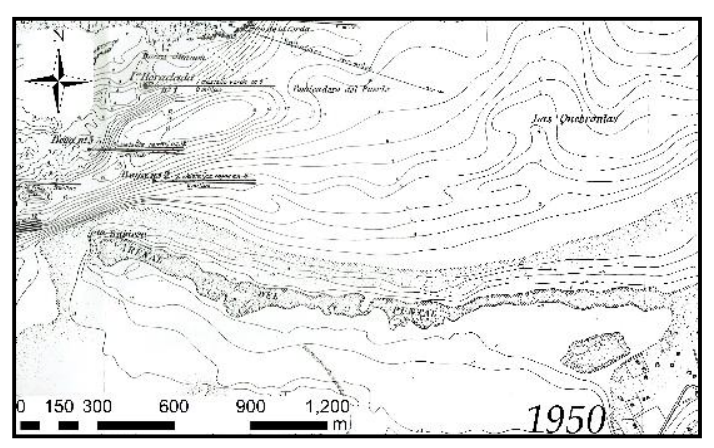

(d)

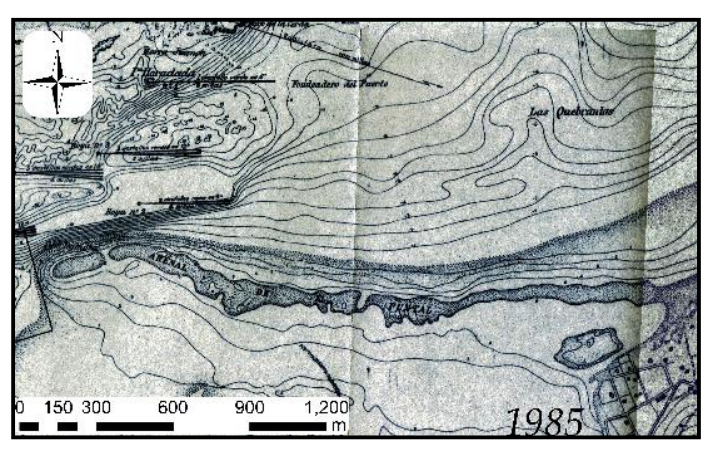

(e)

Figure 3. Maps of Somo Beach for the years of (a) 1875, (b) 1908, (c) 1920, (d) 1950, and (e) 1985.

Subsequent maps were georeferenced, and the 5-m-level curve was digitalized. Figure 4 shows the degree of fit of the georeferencing of the different cartographies, with maximum errors of $40 \mathrm{~m}$. The fit of the georeferenced digitalizations of the different maps in the area of Puerto Chico were checked against the orthophoto in Figure 4, at $1 \mathrm{~km}$ northeast of Punta Rabiosa (Figure 1).

The curve of the 5-m level was then digitalized on each of the georeferenced maps, as this curve was present on all the maps analyzed (Figure 5). It should be pointed out that the 5-m-level curve is normally situated between the upper part of the backshore and the base of the cliffed dune. 


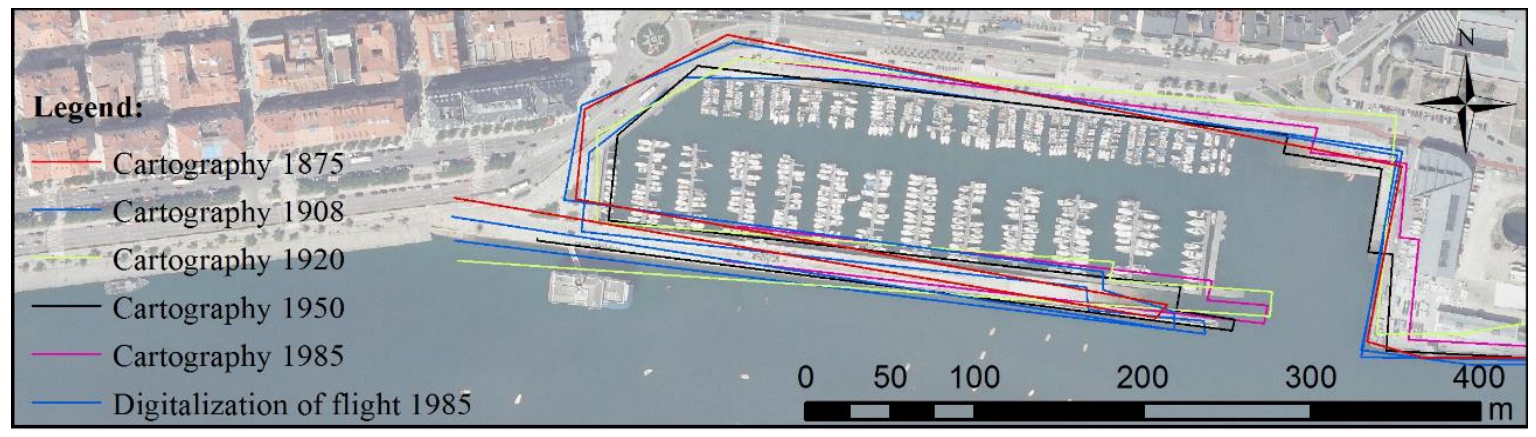

Figure 4. Differences in georeferencing in the digitalizations of the maps of 1875, 1908, 1920, 1950, and 1985. Orthophotography from 2010 (Spatial Data Infrastructure (SDI) Service of the Government of Cantabria, Spain).

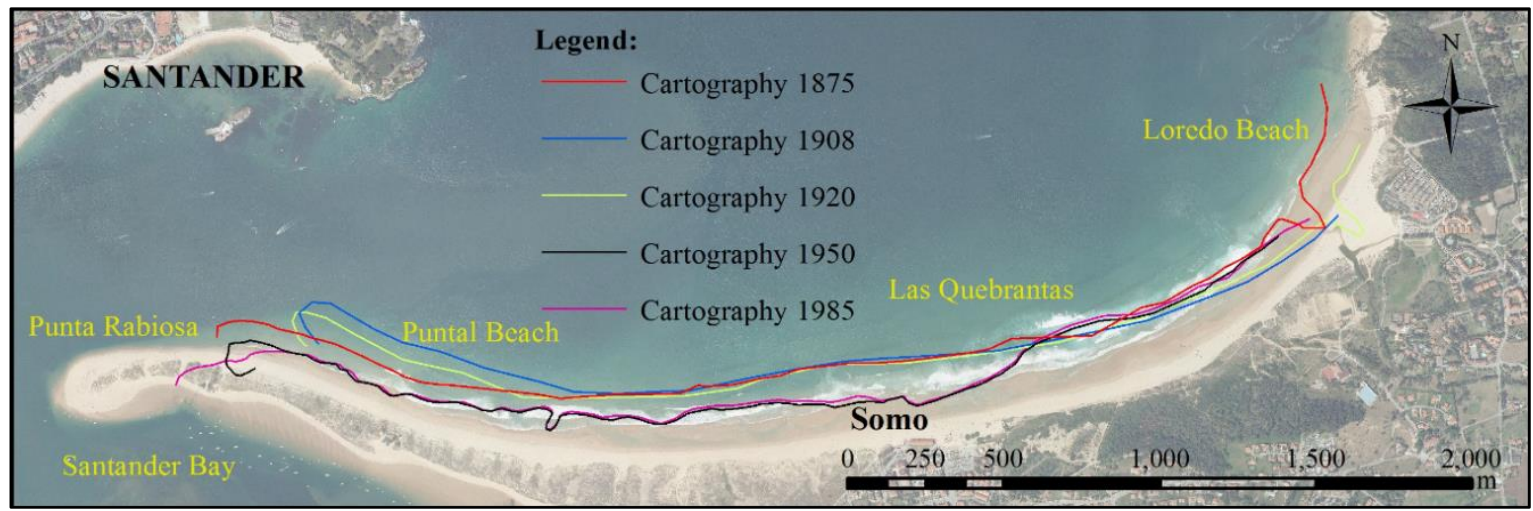

Figure 5. The 5-m-level curve corresponding to the maps of 1875, 1908, 1920, 1950, and 1985. Orthophotography from 2010 (SDI Service of the Government of Cantabria, Spain).

\subsection{Photogrammetric Analysis (1985-2014)}

Photogrammetric flights were made over the city of Santander since 1946, but those made prior to 1985 could not be taken into consideration because of their low quality. Therefore, the flights available from 1985 to 2014 were as follows:

- Flights without photogrammetric information $(1985,1988$, and 2001): There is no certification of camera calibration. The aerial photography was rectified using points situated on the beach, and later, the front of the sandy slope was digitalized.

- Photogrammetric flights $(2005,2007,2010$, and 2014): These are of good photogrammetric quality and open up the possibility of orienting pairs of photographs and generating stereoscopes. Camera calibrations were certified and mapping was performed in the digital stereoplotter, Digi 3D.

The upcoming section analyzes the two possible interpretations of the photogrammetric sessions (digitalization and restitution).

\subsubsection{Digitalization of Photogrammetric Flights (1985-2001)}

The flights in 1985, 1988, and 2001 were rectified using the program ArcMap of ArcGIS. To make the rectification, nearby control points on the shore (level zero) were used, and the upper part of the slope of the sandy front was later digitalized (Figure 6). During this period (1985-2001), a retreat in the shoreline in this area was detected. 


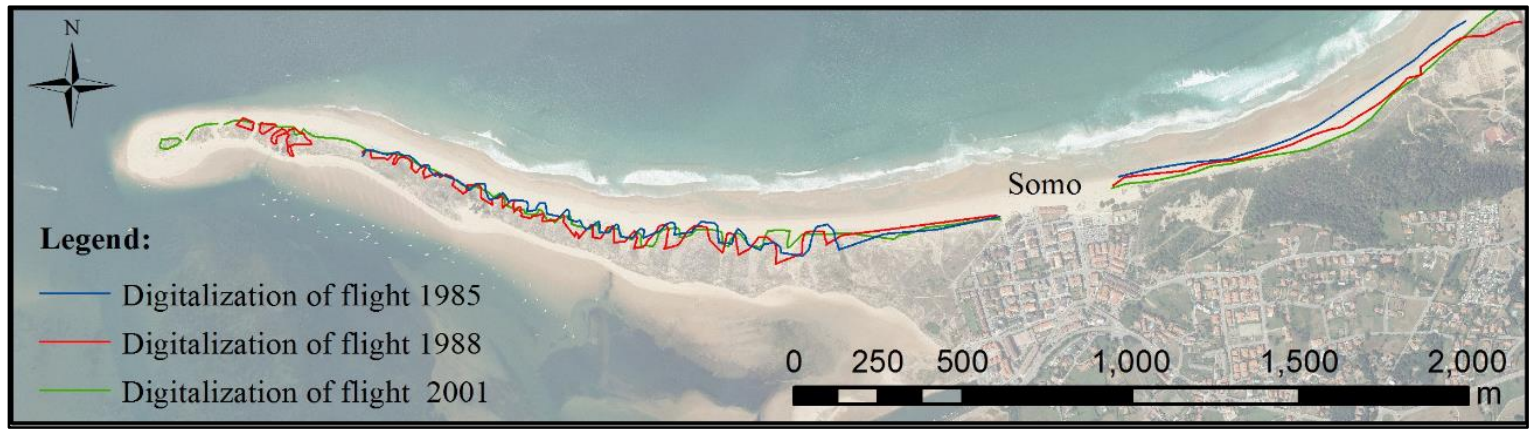

Figure 6. Digitalization of flights (1985, 1988, and 2001) of Somo Beach. Orthophotography from 2010 (SDI Service of the Government of Cantabria, Spain).

The comparison between the digitalizations of maps from 1985 (Figure 5) and the flight of 1985 (Figure 6) show planimetric differences of over $200 \mathrm{~m}$ between the 5-m-level curve on the maps and the upper part of the sandy slope from the 1985 flight (Figure 7). Figure 4 shows that it is not a problem of georeferencing, and we can, therefore, interpret that the maps from 1985 fail to reflect the true condition of Somo Beach. The reason for this is that the Port Authority of Santander used the same map from 1950 to 1985 (see the maps of 1950 and 1985 in Figure 3). Both maps represent the mouth of the bay and its bathymetry, information indispensable to navigation for access to the Port of Santander; however, the rest is identical on both maps. Therefore, the map of 1985 was discarded and the digitalization of the aerial photography of the same year was used.

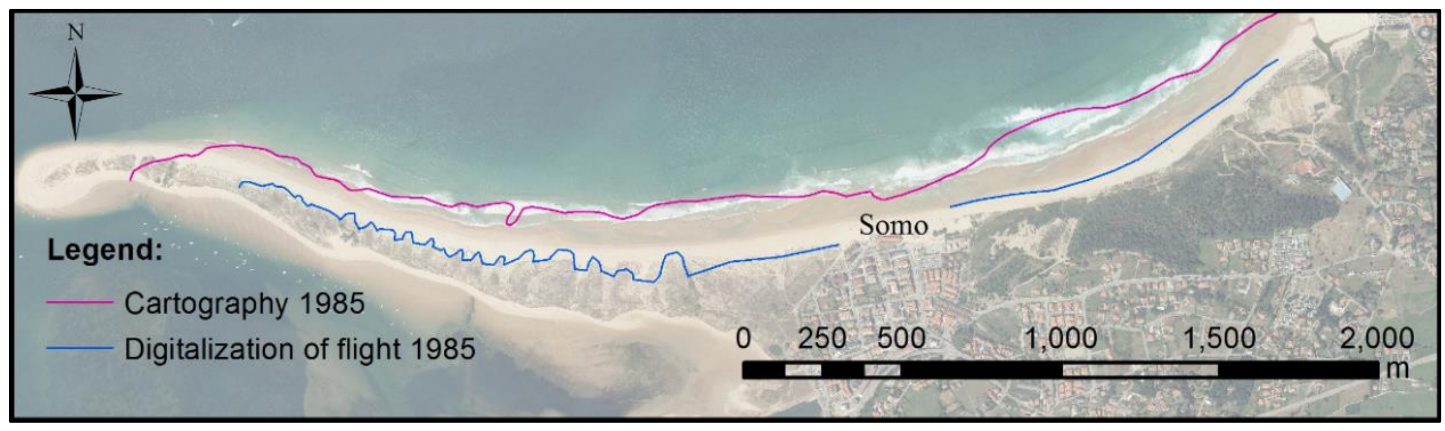

Figure 7. Comparison of digitalizations of the cartography 1985 and of the flight of 1985. Orthophotography from 2010 (SDI Service of the Government of Cantabria, Spain).

\subsubsection{Photogrammetric Restitutions (2005-2014)}

The calibration of the cameras used on the photogrammetric flights in 2005, 2007, 2010, and 2014 by the Spatial Data Infrastructure (SDI) Service of the Government of Cantabria was certified. This fact provides sufficient assurance of quality to be able to draw up the cartography on a $1 / 2500$ scale, in which the maximum error in the orientation of flights must not be over $0.5 \mathrm{~m}$ (Table 2).

The orientation of the photographs of these flights was determined following the General Process of Photogrammetry [40], which consists of internal and external orientation. For internal orientation, the certificate of calibration of the camera is required (focal distance, coordinates of the fiducial marks, and distortion function of the lenses); for the external orientation, the coordinates of the support and control points in ETRS 89 are needed. The support points are those used in the orientation of the various cartographies for flights in 2005, 2007, 2010, and 2014, and they are always the same ones. The control points are the support points not used in the external orientation. On each of the photogrammetric restitutions on a scale of $1 / 2500$, the same control points were measured and the difference in the coordinates was analyzed. These did not surpass the maximum value of $0.5 \mathrm{~m}$ in any of the coordinates $(x, y$, and $z$ ) (Table 2$)$. 
Table 2. Difference in coordinates of the control points for the different flights $(2005,2007,2010$, and 2014). Coordinates are in ETRS 89 and the origin of altitudes is the mean sea level in Alicante (Spain).

\begin{tabular}{|c|c|c|c|c|c|c|c|c|}
\hline Point & Coordinate & Year 2005 & Year 2007 & Year 2010 & Year 2014 & $\begin{array}{l}\text { Difference } \\
\quad \text { in } x\end{array}$ & $\begin{array}{l}\text { Difference } \\
\quad \text { in } y\end{array}$ & $\begin{array}{l}\text { Difference } \\
\quad \text { in } z\end{array}$ \\
\hline \multirow{3}{*}{1} & $x$ & $441,240.502$ & $441,240.947$ & $441,240.656$ & $441,240.911$ & $\begin{array}{c}\text { 2007-2005: } \\
0.445 \mathrm{~m}\end{array}$ & \multirow{3}{*}{$\begin{array}{c}\text { 2014-2007: } \\
0.499 \mathrm{~m}\end{array}$} & \\
\hline & $y$ & $4,812,198.858$ & $4,812,198.384$ & $4,812,198.881$ & $4,812,198.883$ & & & \\
\hline & $z$ & 6.034 & 6.491 & 6.303 & 6.197 & & & $\begin{array}{c}\text { 2007-2005: } \\
0.457 \mathrm{~m}\end{array}$ \\
\hline \multirow{3}{*}{2} & $x$ & $440,874.853$ & $440,874.947$ & $440,874.986$ & $440,874.947$ & $\begin{array}{c}\text { 2010-2005: } \\
0.133 \mathrm{~m}\end{array}$ & \multirow{3}{*}{$\begin{array}{c}\text { 2014-2010: } \\
0.498 \mathrm{~m}\end{array}$} & \\
\hline & $y$ & $4,811,762.369$ & $4,811,762.654$ & $4,811,762.266$ & $4,811,762.764$ & & & \\
\hline & $z$ & 33.641 & 34.002 & 33.506 & 33.584 & & & $\begin{array}{c}2007-2010: \\
0.496 \mathrm{~m}\end{array}$ \\
\hline \multirow{3}{*}{3} & $x$ & $441,367.931$ & $441,367.949$ & $441,367.748$ & $441,367.481$ & $\begin{array}{c}\text { 2007-2014: } \\
0.468 \mathrm{~m}\end{array}$ & \multirow{3}{*}{$\begin{array}{c}\text { 2010-2014: } \\
0.411 \mathrm{~m}\end{array}$} & \\
\hline & $y$ & $4,812,533.321$ & $4,812,533.011$ & $4,812,533.384$ & $4,812,532.973$ & & & \\
\hline & $z$ & 12.253 & 12.287 & 11.788 & 11.884 & & & $\begin{array}{c}2007-2010: \\
0.499 \mathrm{~m}\end{array}$ \\
\hline \multirow{3}{*}{4} & $x$ & $441,327.687$ & $441,327.666$ & $441,327.509$ & $441,327.660$ & $\begin{array}{c}\text { 2005-2010: } \\
0.178 \mathrm{~m}\end{array}$ & \multirow{3}{*}{$\begin{array}{c}\text { 2010-2014: } \\
0.335 \mathrm{~m}\end{array}$} & \\
\hline & $y$ & $4,812,791.151$ & $4,812,791.116$ & $4,812,791.273$ & $4,812,790.938$ & & & \\
\hline & $z$ & 9.326 & 9.327 & 8.835 & 8.829 & & & $\begin{array}{c}\text { 2007-2014: } \\
0.498 \mathrm{~m}\end{array}$ \\
\hline \multirow{3}{*}{5} & $x$ & $441,270.233$ & $441,270.492$ & $441,270.456$ & $441,269.998$ & $\begin{array}{c}\text { 2007-2014: } \\
0.494 \mathrm{~m}\end{array}$ & \multirow{3}{*}{$\begin{array}{l}\text { 2007-2010: } \\
0.047 \mathrm{~m}\end{array}$} & \\
\hline & $y$ & $4,812,287.476$ & $4,812,287.488$ & $4,812,287.441$ & $4,812,287.448$ & & & \\
\hline & $z$ & 2.676 & 2.465 & 2.217 & 2.359 & & & $\begin{array}{c}2005-2010: \\
0.459 \mathrm{~m}\end{array}$ \\
\hline \multirow{3}{*}{6} & $x$ & $440,823.517$ & $440,823.428$ & $440,823.290$ & $440,823.428$ & $\begin{array}{c}2005-2010: \\
0.227 \mathrm{~m}\end{array}$ & \multirow{3}{*}{$\begin{array}{c}\text { 2010-2007: } \\
0.400 \mathrm{~m}\end{array}$} & \\
\hline & $y$ & $4,812,064.215$ & $4,812,064.070$ & $4,812,064.470$ & $4,812,064.070$ & & & \\
\hline & $z$ & 8.749 & 8.266 & 8.427 & 3.318 & & & $\begin{array}{c}\text { 2005-2014: } \\
5.431 \mathrm{~m}\end{array}$ \\
\hline
\end{tabular}

Maximum difference of coordinates: $x$ (point 5): $0.494 \mathrm{~m} ; y$ (point 1): $0.499 \mathrm{~m} ; z$ (point 3): $0.499 \mathrm{~m}$.

Coordinate $z$ in Table 2 indicates the particular situation of point 6 owing to its disappearance following the winter storms in 2013-2014, the origin position (2010) of which is shown in Figure 8a, and the situation in 2014 is shown in Figure $8 \mathrm{~b}$. The flight of 2014 was, therefore, given the same planimetric coordinates as the flight of 2010 and its altimetric position $(3.318 \mathrm{~m})$ was determined. The loss of level at this point between 2005 and 2014 was $5.431 \mathrm{~m}$. Between 2010 and 2014, loss was $5.109 \mathrm{~m}$, and this value was later taken into account to evaluate the influence of the storms of 2013-2014.

Once the process of photogrammetric orientation was complete, the upper part of the slope of the sandy front was restituted (Figure 9). Both the digitalized cartography and photogrammetric flights prior to 2005 and the photogrammetric restitutions used the ETRS 89 system of coordinates. In order to check the fit of the georeferencing, common elements were used, such as the corners of houses, crossroads, or the corners of fields. The maximum differences between the digitalizations (cartography and photogrammetry) and the photogrammetric restitutions were no greater than $40 \mathrm{~m}$. 


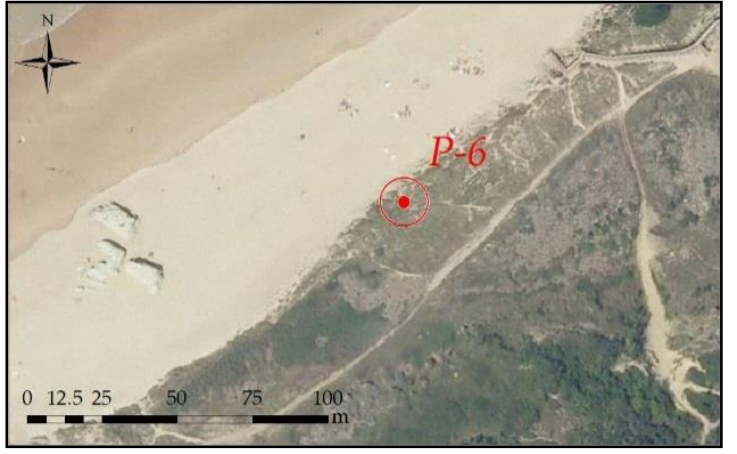

(a)

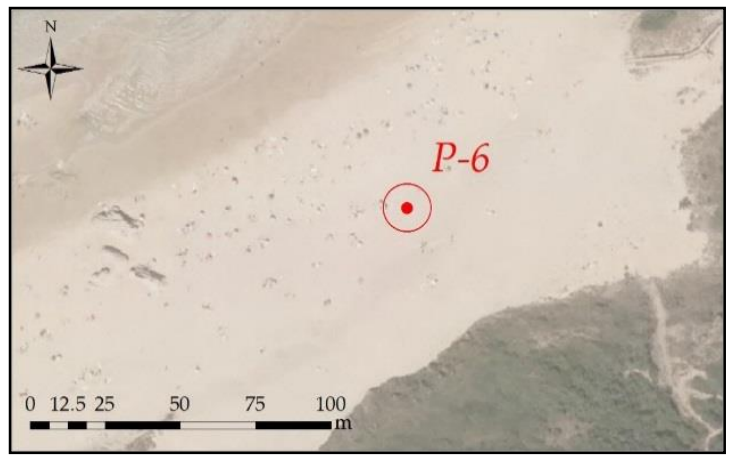

(b)

Figure 8. (a) Position of control point 6 in the orthophotographs of 2010; (b) point 6 in the orthophotographs of 2014. SDI Service of the Government of Cantabria, Spain.

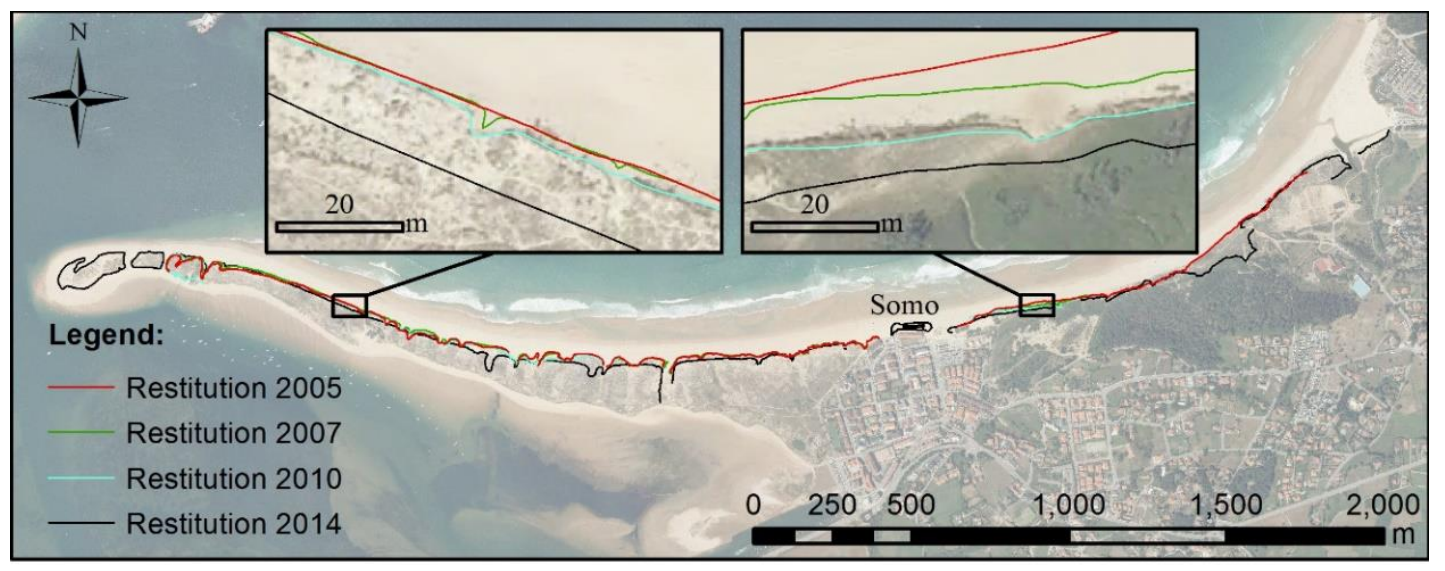

Figure 9. Restitutions of aerial flights $(2005,2007,2010$, and 2014) of Somo Beach, in which only the upper part of the slope of the sandy front is represented. Orthophotography from 2010 (SDI Service of the Government of Cantabria, Spain).

\subsection{Topographical Measurement (1988-1993)}

For the topographical bathymetric monitoring of the beach of Somo between 1988 and 1993, 13 profiles (P1, P1', P2, P3, ... , P8) were measured monthly (Figure 10a) [10,41]. The bathymetry was observed at high tide and the topographical land measurement at low tide in order to obtain the intertidal overlap between the bathymetric measurements (profile with one sounding on the vessel) and the terrestrial ones (topographical profile on the beach).

An analysis of the topographical profiles throughout of Somo Beach during the period 1988-1993 reveals few changes to the retreat of the shoreline in the area of Las Quebrantas. However, if we observe the photogrammetric restitution of 2005, the large retreat of the coast in Las Quebrantas between 1988 and 2005 is seen. Since 2011, research was, therefore, centered on the area of Las Quebrantas, where TLS data were collected [42,43]. 


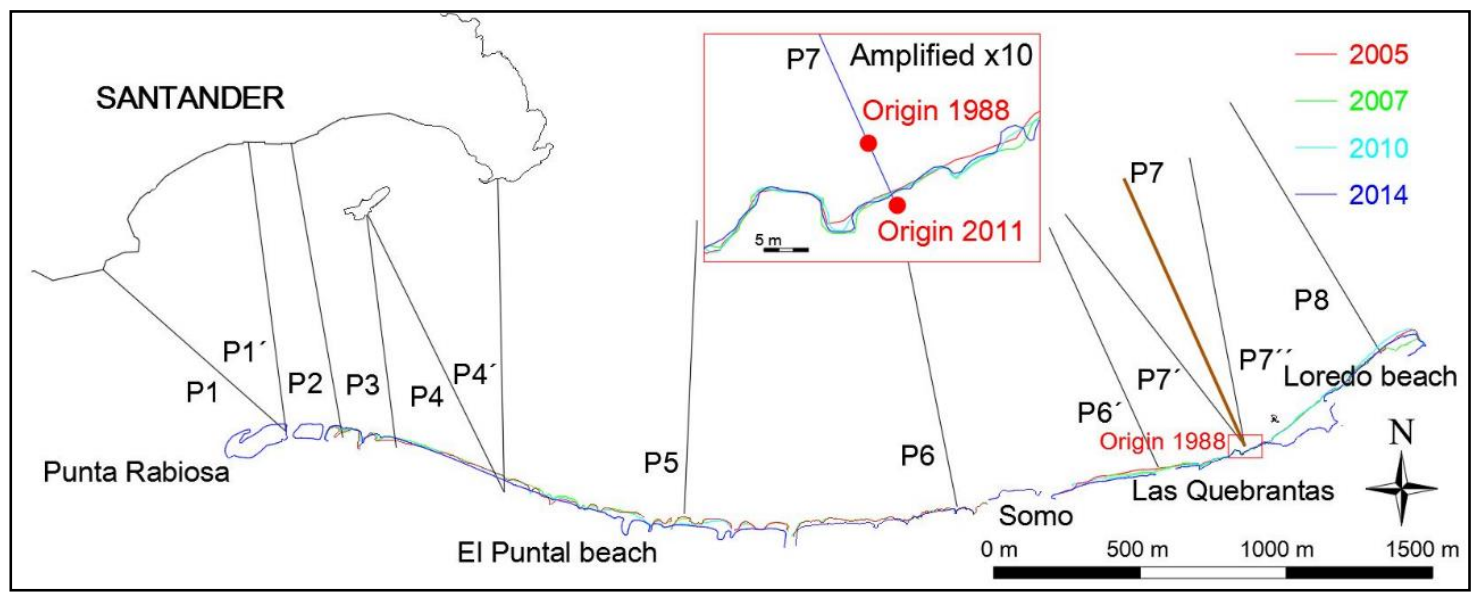

(a)

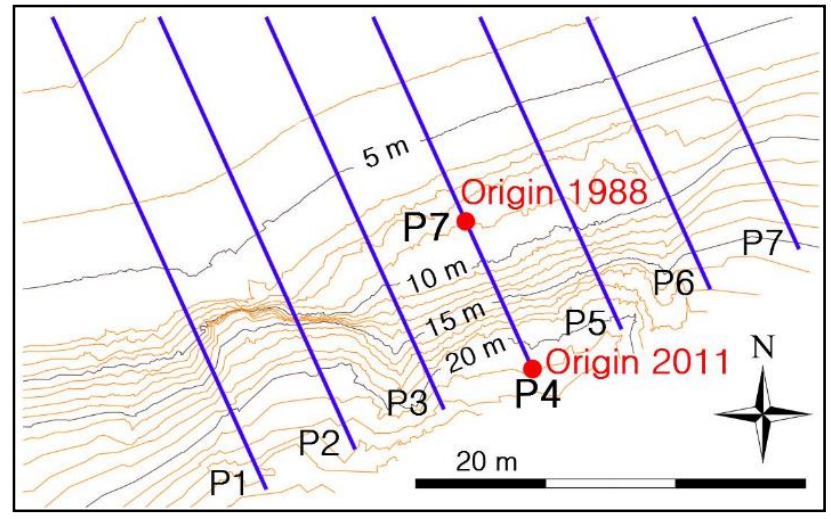

(b)

Figure 10. (a) Planimetric representation of the 13 topographic profiles (1988-1993) on the photogrammetric cartography $(2005,2007,2010$, and 2014). The topographic, photogrammetric, and terrestrial laser scanning (TLS) data collection area are also amplified $\times 10$. (b) The seven profiles of measurement using photogrammetry and TLS over the cartography generated by TLS in 2011 are shown. Profile 4 (P4) coincides with the measurement of profile 7 (P7) in the period of 1988-1993. The position of the base in 1988 is also indicated.

\subsection{Terrestrial Laser Scanner (2011-2017)}

The application of terrestrial laser scanning (TLS) for the monitoring and analysis of geomorphological dynamics on sandy coasts with millimetric precision is relatively recent and entirely efficient even at detecting annual changes [44], as well as complementing traditional analytical methods. TLS has functional sensitivity under adverse meteorological conditions [45] and a versatility that permits monitoring at any time. It has proven reliability on the coasts of the Cantabrian Sea in the study area, on confined beaches nearby, and in the ongoing observation of sand banks $[42,43,46,47]$.

The use of TLS in the area of Las Quebrantas provided seven profiles, as shown in Figure $10 \mathrm{~b}$. The number of points measured with TLS in each survey was approximately 500 million with a precision at each point of $3 \mathrm{~cm}$ including the GNSS error. Two measurements were made per year to evaluate the evolution of the beach during the winter (October-March) and the summer (April-September).

A shoreline of $400 \mathrm{~m}$ was selected to make the TLS measurements coincide with those from previous periods. In this way, profile 4 (P4) taken with TLS (2011-2017) is the same as profile 7 (P7), which was measured using topographical techniques (1988-1993), and this same profile 7 (P7) was collected using photogrammetry (2005-2014) (Figures 11 and 12). 


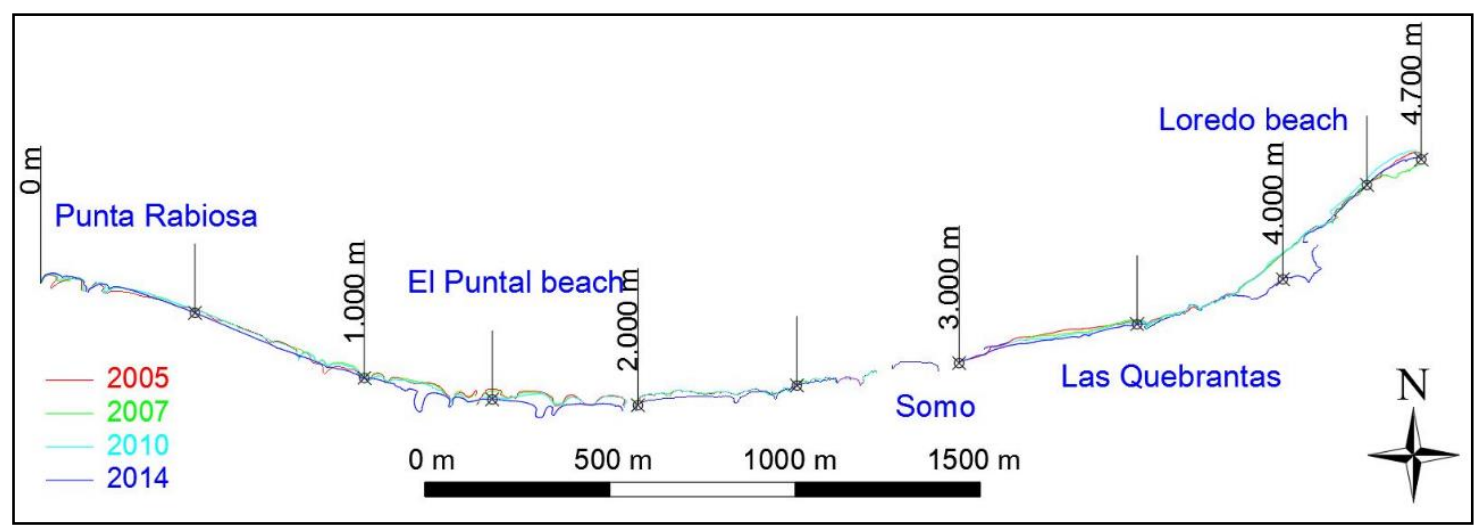

(a)

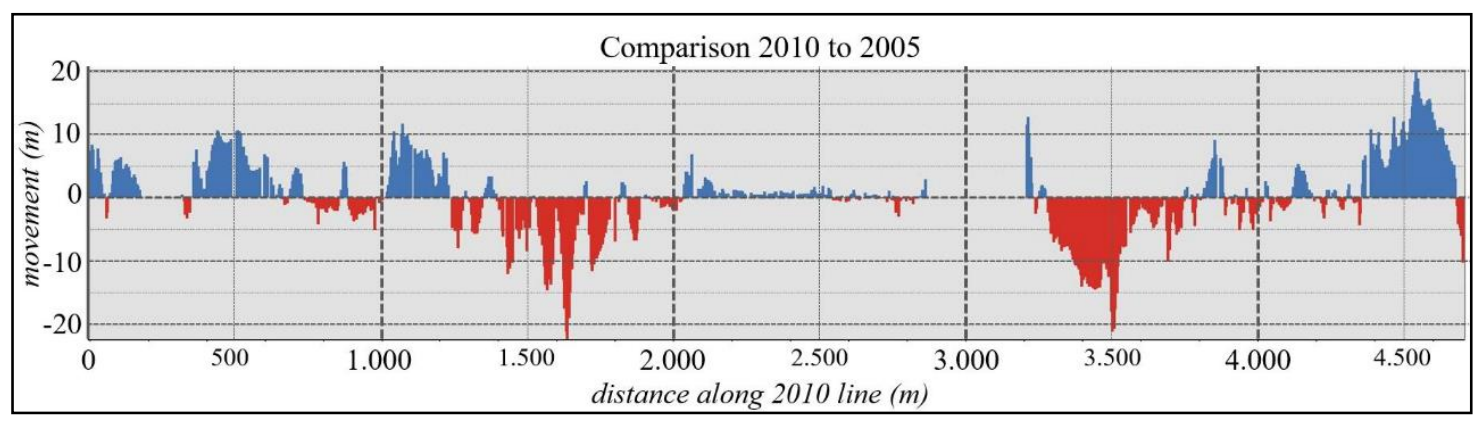

(b)

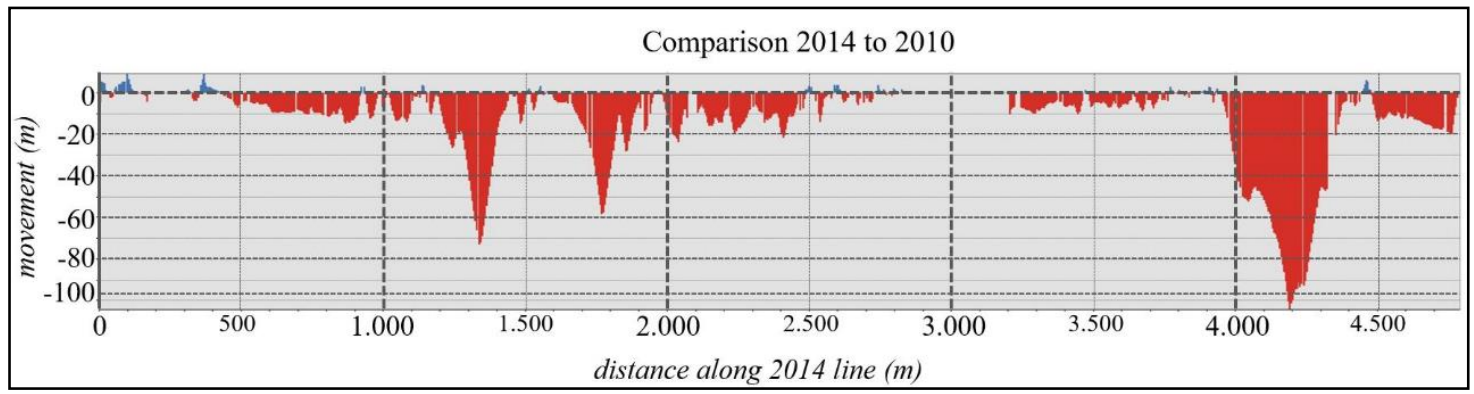

(c)

Figure 11. (a) Restitutions of the slope of the sandy front in 2005, 2007, 2010, and 2014. (b) Comparison of the evolution of the shorelines restituted in 2005 and 2010. (c) Comparison of the evolution of the shorelines restituted in 2010 and 2014.

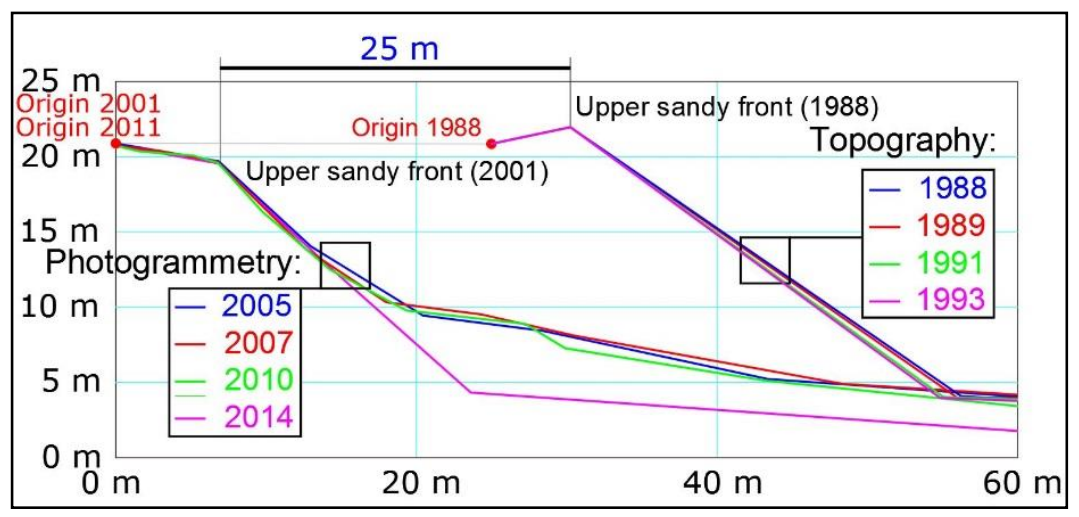

Figure 12. Topographical measurements of profile 4 (Figure 10b) between 1988 and 1993, and photogrammetric evolution of profile 4 between 2005 and 2014. 


\section{Results and Discussion}

The geomatic techniques developed in the study of Somo Beach have maximum errors in the cartographic production for the calculation of the coastal retreat (Table 3).

Table 3. Maximum errors obtained with each geomatic method.

\begin{tabular}{cc}
\hline Geomatic Method & Maximum Error (m) \\
\hline Cartography (1875-1985) & 40.00 \\
Photogrammetry (1985-2014) & 0.50 \\
Topography (1988-1993) & 0.07 \\
Terrestrial Laser Scanner (2011-2017) & 0.03 \\
\hline
\end{tabular}

To determine the numerical values of the evolution of the shoreline, the beach of Somo was divided into two parts: the sandy strips between Punta Rabiosa and Somo (El Puntal Beach), and the cliffed dune between Somo and Loredo Beach (Las Quebrantas Beach) (Figure 1).

The results obtained between Punta Rabiosa and Somo between 1875 and 2014 were as follows:

- Cartography of 1875, 1908, 1920, and 1950, and digitalization of the flight in 1985: The curve of the 5-m level in Punta Rabiosa between 1875 and 1920 indicates a turn from west to northeast (Figure 5). In the period of 1950-1985, it underwent a deviation in its trajectory toward the west (Figure 5). This change in direction is still ongoing today and is possibly because of dredging at the mouth of the bay of Santander. There are estimates indicating that, from 1870 to the present, Punta Rabiosa grew by $1075 \mathrm{~m}$ toward the west [20], while [48] some estimate this growth to be $425 \mathrm{~m}$ since 1926. During this period (1875-2017), our calculations determine a westward advance of $470 \mathrm{~m}$.

- This area of the El Puntal Beach retreated southward due to erosion, a process that is ongoing. There was an estimate of the shoreline retreat of $100 \mathrm{~m}$ between 1929 and 1960 [10], while Reference [48] suggests a retreat of $200 \mathrm{~m}$ between 1920 and 1985 (Table 4). Our calculations indicate a retreat of around $200 \mathrm{~m}$ between 1950 and 1985, and of approximately $375 \mathrm{~m}$ from 1875 to 1985 (Table 4).

- Digitalizations of the flights in 1985, 1988, and 2001: The coastal retreat in this period was $25 \mathrm{~m}$.

- Digitalization of the flight in 2001 and the photogrammetric restitutions of the flights in 2005, 2007, 2010, and 2014 (Figure 11a): From 2005 to 2010, there was a mean retreat of the shoreline of $5 \mathrm{~m}$, although there are sections with retreats of over $20 \mathrm{~m}$ and others that advanced in the period (Figure 11b). Between 2010 and 2014, there was an accentuated retreat of the shoreline, particularly in the winter of 2013-2014 as a result of large storms that hit the Cantabrian Sea (Figure 11c). The estimated retreat in this area during these storms was $10 \mathrm{~m}$. Thus, in the 2001-2014 period, there was a retreat of around $15 \mathrm{~m}$.

Table 4. Summary of the historical evolution of El Puntal Beach.

\begin{tabular}{ccccc}
\hline Date & Total Years & Retreat $(\mathbf{m})$ & Retreat $(\mathbf{m} / \mathbf{y r})$ & Authors \\
\hline $1929-1960$ & 31 & 100 & 3.2 & {$[10]$} \\
$1920-1985$ & 65 & 200 & 3.1 & {$[48]$} \\
\hline $1875-1985$ & 110 & 375 & 3.4 & \\
$1950-1985$ & 35 & 200 & 5.7 & {$[41-43]$} \\
$1875-2014$ & 139 & $415 \pm 40$ & $2.7-3.3$ & \\
\hline
\end{tabular}

In total, the retreat in the area between Punta Rabiosa and Somo between 1875 and 2014 was $415 \mathrm{~m}$ with a margin of uncertainty of $40 \mathrm{~m}$ in the cartographic digitalizations (Table 4). It should be pointed out that these results are close to those of References $[10,48]$. 
The study of the changes in the area between the village of Somo and Loredo Beach, known as Las Quebrantas Beach, for the period of 1875-2017 indicates the following:

- The cartography of $1875,1908,1920$, and 1950, and the flight of 1985: The values of coastal retreat are the same as those of the rest of the El Puntal Beach, that is, $375 \mathrm{~m}$.

- Digitalization of the flights in 1985, 1988, and 2001: The retreat of the shoreline during the period was $30 \mathrm{~m}$. Within this period, the analysis of the topographical profile (P4) between 1988 and 1993 showed a retreat of less than $1 \mathrm{~m}$ (Figure 12). Between the topographical profile of 1993 and the photogrammetric restitution of 2005, the shoreline retreated by $25 \mathrm{~m}$ given that the upper part of the slope of the sandy front between 1988 and 1993 was found to be $25 \mathrm{~m}$ farther out to sea with respect to 2005.

- Digitalization of the flight in 2001 and photogrammetric restitutions of the flights in 2005, 2007, 2010, and 2014: There was hardly any retreat in the foredune ridge between 2001-2014, although this was not the case at the base of the slope of the sandy front, which was affected by the winter storms of 2013-2014 (Figure 12). These variations were analyzed in greater detail using TLS.

- Terrestrial laser scanning (TLS): Measurements taken using TLS in the period from August 2011 to November 2013 show stability with slight variations in the intertidal area. In April 2014, large retreats are seen with respect to the measurements made in November 2013 (Figure 13) and these coincide with the photogrammetric measurements (Figure 12). The retreat of the base of the slope of the sandy front in the position of profile 4 between November 2013 and April 2014 was $8 \mathrm{~m}$. The fall in the level of the entire beach by $3 \mathrm{~m}$ was also significant, even as much as $5.431 \mathrm{~m}$ in some areas (point 6) (Table 2). From April 2014 to April 2017, the upper part of the slope retreated by $2 \mathrm{~m}$, stabilizing the gradient of the sandy slope (Figure 13).

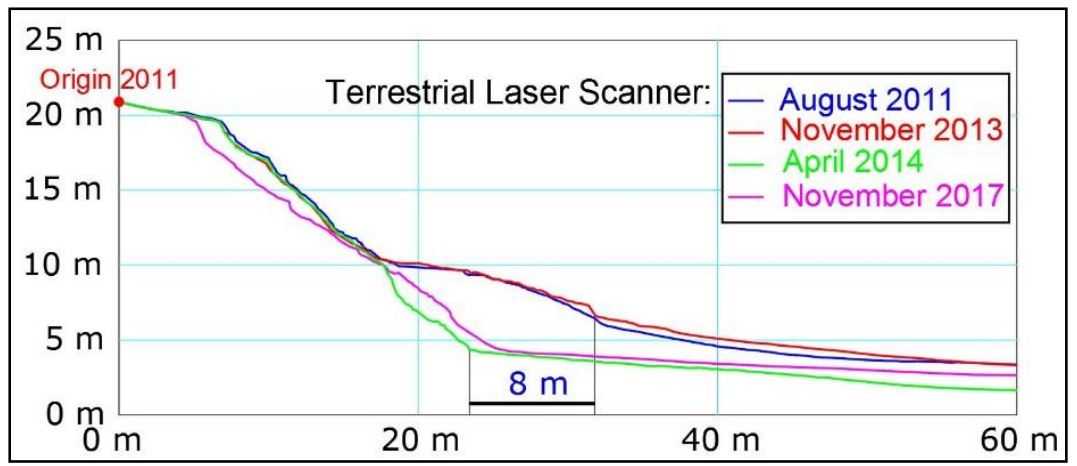

Figure 13. Evolution of profile 4 (Figure 10b) with TLS between August 2011 and November 2017.

There were estimates indicating a retreat of $210 \mathrm{~m}$ between 1870 and 1926 in this area of the beach, and of $200 \mathrm{~m}$ between 1920 and 1985 [48] (Table 5). Our research indicates that, between 1875 and 1985, this retreat was $375 \mathrm{~m}$, and, between 1985 and 2017, the retreat was $32 \mathrm{~m}$ (Table 5). This area of Las Quebrantas Beach, thus, suffered a retreat of $407 \mathrm{~m}$ with an uncertainty of $40 \mathrm{~m}$ from 1875 to the present (2017).

Table 5. Summary of the historical evolution of the beach of Las Quebrantas.

\begin{tabular}{ccccc}
\hline Date & Years & Retreat $(\mathbf{m})$ & Retreat $(\mathbf{m} / \mathbf{y r})$ & Authors \\
\hline $1870-1926$ & 56 & 210 & 3.7 & Badía, 2003 \\
$1920-1985$ & 65 & 200 & 3.1 & Sanjosé et al., in this work \\
\hline $1875-1985$ & 110 & $375 \pm 40$ & $3.0-3.8$ & 1.0 \\
$1985-2017$ & 32 & 32 & & \\
\hline
\end{tabular}


Analyzing the results obtained between 1985 and 2017, large retreats of the shoreline are seen between 1993 and 2001 (Figure 12), as well as following the storms between December 2013 and March 2014 (Figure 13). There is a correspondence, therefore, with the data of Table 1, in which we see that the five-year periods of 1995-1999 and 2010-2014 were the most active since the series of swells became available (1985). To be specific, 1999 was outstanding in the series, as there were eight days with storms that year, and more recently, 2014, when there were six days of storms in February and the first week of March, of which four days had tidal range of over 100.

The village affected by this coastal dynamic is Somo, located between El Puntal Beach and Las Quebrantas Beach. For the period of 1985-2017, the coast retreated by $32 \mathrm{~m}$ in this area (Table 5). Somo used to be a village with small individual houses; however, at the beginning of the 1980s, housing estates and attached houses began being built, some of them on the beach front. It is these buildings that this coastal retreat is now affecting, mainly when the swells are higher than $6 \mathrm{~m}$, coinciding with periods of high tidal range of over 100 (Figure 14).

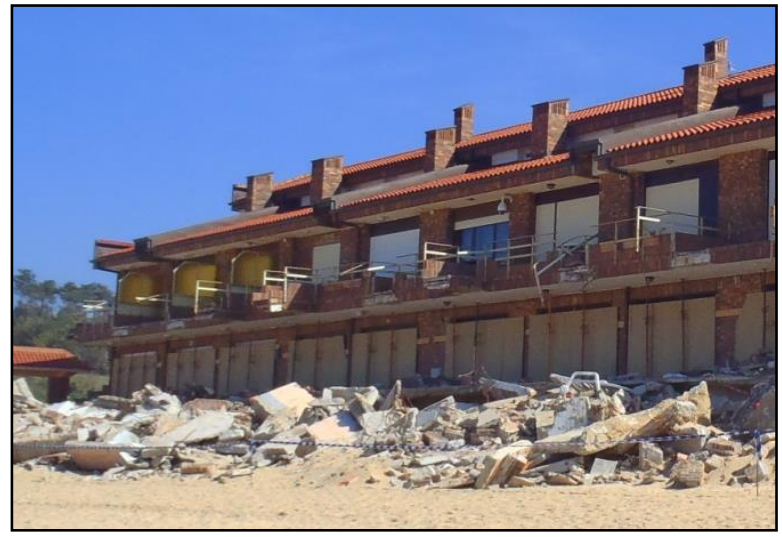

Figure 14. Damaged houses in the urban area of Somo due to the winter storms of 2013-2014.

\section{Conclusions}

The techniques and sources used to analyze the evolution of the coastal sandy system were useful in determining the retreat of the coast over the last 142 years. The geomatic techniques used were cartography, photogrammetry, topography, terrestrial laser scanning (TLS), and georeferencing with the global navigation satellite system (GNSS), which were effective for observing ongoing changes in the coastal system. The combination and complementarities of different techniques and sources, such as historical cartography, photogrammetric flight series, and TLS, were very useful to know the evolution and erosive rhythms on the foredune. The behavior of the entire beach was uniform over the long time scale between 1875 and 2017, with an overall retreat of around $415 \mathrm{~m}$; however, differences could be established in short time scales. The retreat of the shoreline was $25 \mathrm{~m}$ between 1985 and 2001 in El Puntal Beach and between 1993 and 2005 in the area of Las Quebrantas Beach. A faster retreat took place during the period of 1995-1999 (Table 1) characterized by the large number of strong storms [40]. Between 2010 and 2014, there were large storms, four of which came in the winter of 2013-2014, and the beach underwent a mean retreat of $8 \mathrm{~m}$ at the foredune base. These four storms coincided with tidal ranges of over 100, swells higher than $6 \mathrm{~m}$, and periods of high tides.

The storms that took place between December 2013 and March 2014 were exceptional because of their coincidence with large tidal coefficients, low atmospheric pressures, and successions of waves grouped together, which had a constant erosive effect on the beaches with the export of sediment and a significant retreat of the shoreline. The strong retreats of the shoreline in the coastal sandy systems were generated in extraordinary periods, as shown by what happened in the four months of the winter of 2013-2014, associated with extreme storms and erosive rates far higher than those estimated for the other periods analyzed. From April 2014 to April 2017, six TLS data collections were made, and the foredune talus slope stabilized with the beach recovered its original level. 
The rock cliff previously covered by the foredune appeared in 1999, and in November 2016, $130 \mathrm{~m}$ to the east, a new outcrop rock arose on top of the dune (Figure 15). These dune erosive processes can generate significant changes, producing a continuous cliff without dunes if the erosive processes remain.

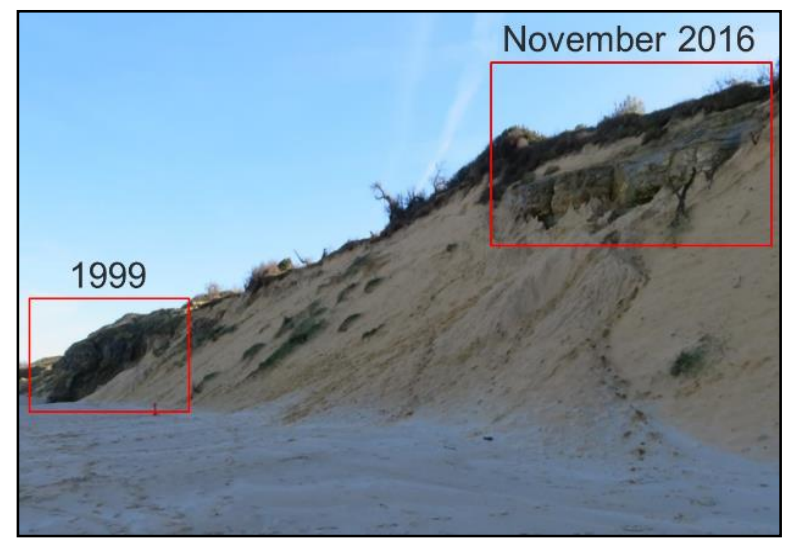

Figure 15. New outcrop of the rock cliff in the year 1999 and in November 2016.

The use of geomatic techniques can allow precision measurements to be made in the future complemented by other means (satellite photography, drone flights) to determine recent coastal evolution and its current dynamic with greater accuracy. The build-up of a long storm data series will improve knowledge of the retreat of the shoreline, trends and erosive rates, and accumulation, as well as the response of the natural system of the sea-land contact strip in the context of global change, and as indicators of sea level change. We consider that the behavior analyzed in this article is similar to that which occurs in the world's dune fronts with similar characteristics, and that their retreats are also affected by large storms.

Author Contributions: J.J.d.S.B. conceived, designed and carried out the project and the manuscript. M.G.-L., M.S.-F., E.S.-C. shared the project and helped record information in the field and to write the manuscript, and during the publication process.

Acknowledgments: This research was made possible thanks to funding by the Junta de Extremadura and ERDF, through the references GR18053 to the Research Group NEXUS (University of Extremadura), and by the I+D+I project CGL2015-68144-R (MINECO, Spanish Government and ERDF), and the Research Group PANGEA (University of Valladolid). We thank the SDI Service of Government of Cantabria for providing the aerial photographic information.

Conflicts of Interest: The authors declare no conflict of interest.

\section{References}

1. Medina, R.; Losada, M.; Dalrymple, R. Análisis de perfiles de playa por medio de funciones ortogonales empíricas (método FOE). Revista de Obras Públicas 1990, 3292, 9-17.

2. Izaguirre, C.; Losada, Í; Méndez-Incera, F.; Díaz-Simal, P.; Lara, J.L.; Ondiviela, B.; Jiménez Toribio, M. Flooding and erosion risk analysis in santander bay, spain. In En: Coastal Riks Management in a Changing Climate; Zanuttigh, B., Nicholls, R., Vanderlinden, J.P., Burcharth, H.F., Thompson, R.C., Eds.; Butterworth-Heinemann: Waltham, MA, USA, 2015; pp. 559-591.

3. Villatoro, M.; Silva, R.; Méndez, F.J.; Zanuttigh, B.; Pan, S.; Trifonova, E.; Losada, I.J.; Izaguirre, C.; Simmonds, D.; Reeve, D.E.; et al. An approach to assess flooding and erosion risk for open beaches in a changing climate. Coast. Eng. 2014, 87, 50-76. [CrossRef]

4. Martínez-Cedrún, P.; Flor, G.; Flor-Blanco, G.; Fernández Maroto, G. Relaciones texturales y composición mineralógica de los sistemas de playa/dunas en una costa rocosa: caso de Cantabria (NO de España). Revista de la Sociedad Geológica de España 2014, 27, 13-27. 
5. Losada, I.J.; Izaguirre, C.; Diaz-Simal, P. Cambio Climático en la Costa Española. Plan Nacional de Adaptación al Cambio Climático; Ministerio de Agricultura, Alimentación Y Medio Ambiente: Madrid, Spain, 2014.

6. Pellón, E.; Garnier, R.; Medina, R. Intertidal finger bars at el puntal, bay of santander, spain: Observation and forcing analysis. Earth Surf. Dyn. Discuss. 2013, 1, 673-710. [CrossRef]

7. Medellín, G.; Medina, R.; Falqués, A.; González, M. Coastline sand waves on a low-energy beach at "el puntal" spit, Spain. Mar. Geol. 2008, 250, 143-156. [CrossRef]

8. Medina, R.; Losada, I.J.; Losada, M.Á.; Vidal, C. Variabilidad de los perfiles de playa: Forma y distribución granulométrica. Ingeniería del agua 1995, 2, 133-142. [CrossRef]

9. Losada, M.A.; Medina, R.; Vidal, C.; Losada, I.J. Temporal and spatial cross-shore distributions of sediment at "el puntal" spit, Santander, Spain. Coastal Eng. 1993, 1992, 2251-2264.

10. Losada, M.; Medina, R.; Vidal, C.; Roldan, A. Historical evolution and morphological analysis of "el puntal" spit, santander (Spain). J. Coast. Res. 1991, 7, 711-722.

11. Lim, S.; Thatcher, C.A.; Brock, J.C.; Kimbrow, D.R.; Danielson, J.J.; Reynolds, B.J. Accuracy assessment of a mobile terrestrial lidar survey at padre island national seashore. Int. J. Remote Sens. 2013, 34, 6355-6366. [CrossRef]

12. Deng, J.; Harff, J.; Dudzinska-Nowak, J. Quantitative method on historical reconstruction of coastal geomorphological change on wave-dominated coast: A case study of the pomeranian bay, southern baltic sea. In Mathematics of Planet Earth; Springer: Berlin/Heidelberg, Germany, 2014; pp. 347-350.

13. Furmańczyk, K.; Andrzejewski, P.; Benedyczak, R.; Bugajny, N.; Cieszyński, Ł.; Dudzińska-Nowak, J.; Giza, A.; Paprotny, D.; Terefenko, P.; Zawiślak, T. Recording of selected effects and hazards caused by current and expected storm events in the baltic sea coastal zone. J. Coast. Res. 2014, 338-342. [CrossRef]

14. Bonte, Y.; Levoy, F. Field experiments of beach scarp erosion during oblique wave, stormy conditions (Normandy, France). Geomorphology 2015, 236, 132-147. [CrossRef]

15. Tysiac, P.; Wojtowicz, A.; Szulwic, J. Coastal Cliffs Monitoring and Prediction of Displacements Using Terrestial Laser Scanning. In Proceedings of the IEEE Geodetic Congress (Geomatics), Gdansk, Poland, 2-4 June 2016; pp. 61-66.

16. Le Mauff, B.; Juigner, M.; Ba, A.; Robin, M.; Launeau, P.; Fattal, P. Coastal monitoring solutions of the geomorphological response of beach-dune systems using multi-temporal lidar datasets (Vendée coast, France). Geomorphology 2018, 304, 121-140. [CrossRef]

17. Medjkane, M.; Maquaire, O.; Costa, S.; Roulland, T.; Letortu, P.; Fauchard, C.; Antoine, R.; Davidson, R. High-resolution monitoring of complex coastal morphology changes: Cross-efficiency of sfm and tls-based survey (Vaches-noires cliffs, Normandy, France). Landslides 2018, 15, 1097-1108. [CrossRef]

18. Terefenko, P.; Giza, A.; Paprotny, D.; Kubicki, A.; Winowski, M. Cliff retreat induced by series of storms at międzyzdroje (Poland). J. Coast. Res. 2018, 181-185. [CrossRef]

19. GIOC. Documento Temático: Regeneración de Playas; Ministerio de medio Ambiente, Universidad de Cantabria (Grupo de Ingeniería Oceanográfica y de Costas): Cantabria, Spain, 2000.

20. Flor-Blanco, G.; Flor, G.; Borghero, C.; de Sanjosé Blasco, J.J.; Gómez-Lende, M. Evolución de la flecha arenosa de somo (santander). Factores naturales y antrópicos. Evolution of the somo sandy spit (santander). Natural and athropogenic factors. Geo-Temas 2016, 16, 275-278.

21. Belmonte, M.; Garzon, J.; Losada, M.; Martinez, R.; Ortega, J. Oyambre Espacio Natural; Estudos Santander: Santander, Spain, 1987; p. 166.

22. Garrote, J.; Garzón, G.; Page, J. Condicionamientos antrópicos en la erosión de la playa de oyambre (Cantabria). Actas V Reunión de Cuaternario Ibérico 2001, 1, 67-70.

23. Garrote, J.; Page, J.; Garzón Heydt, G. Morfodinamica en un Complejo Playa-Ría Bajo Condicionantes Antrópicos; Oyambre: Cantabria, Spain, 2001.

24. Garrote, J.; Heydt, G.; Alcantara Carrio, J. Influencia de Los Temporales Sobre el Transporte de Sedimentos en la Playa de Oyambre (Cantabria, $n$ de España); Dpto. Geografía-UVA: Valladolid, Spain, 2002; pp. 361-371.

25. Lorenzo, F.; Alonso, A.; Pagés, J. Evolución y erosión comparada de tres sistemas playa/flecha en las rías de ortigueira, o barqueiro y viveiro (Galicia, España). Cuaternario y Geomorfología 2003, 17, 75-89.

26. Lorenzo, F.; Alonso, A.; Pagés, J.L. Erosion and accretion of beach and spit systems in northwest spain: A response to human activity. J. Coast. Res. 2007, 23, 834-845. [CrossRef] 
27. Flor-Blanco, G.; Flor, G.; Pando, L. Evolution of the salinas-el espartal and xagó beach/dune systems in north-western spain over recent decades: Evidence for responses to natural processes and anthropogenic interventions. Geo-Mar. Lett. 2013, 33, 143-157. [CrossRef]

28. Flor-Blanco, G.; Pando, L.; Morales, J.A.; Flor, G. Evolution of beach-dune fields systems following the construction of jetties in estuarine mouths (Cantabrian coast, NW Spain). Environ. Earth Sci. 2015, 73, 1317-1330. [CrossRef]

29. Vasco, H.; Garrote, J. Influencia de Los Parámetros que Definen Eventos de Alta Energía en la Costa y su Influencia en la Erosión de Playas. El caso del Complejo Playa-Cordón Dunar de Oyambre (Cantabria). In Proceedings of the III Congreso de la Sociedad de Análisis de Riesgos Latino Americana, Säo Paulo, Brazil, 10-13 May 2016.

30. Flor-Blanco, G.; Flor, G.; Martínez-Cedrún, P.; Bruschi, V. La costa occidental de cantabria (Santander-estuario de Tina Menor). Guía de Excursiones de Campo. XII Reunión Nacional de Geomorfología, Santander 2010, 2012, 25-44.

31. Saiz de Omeñaca, J.; Flor-Blanco, G.; Flor, G.; Barba-Regidor, F.J.; Francés, E.; Bruschi, V.M. La península de la magdalena. In Geolodía; Sociedad Gológica de España: Santander, España, 2013; Volume 4, pp. 1-14.

32. Ramírez del Pozo, J.; Portero García, J.M. Mapa Geológico de España 1/50.000; Instituto Geologico y Minero de España, Ministerio de Economía Industria y Competitividad: Madrid, Spain, 1976; p. 41.

33. Cendrero, A.; Díaz de Terán, J.R.; Salinas, J.M. Environmental-economic evaluation of the filling and reclamation process in the bay of santander, spain. Environ. Geol. 1981, 3, 325-336. [CrossRef]

34. Cereceda, J.D. Evolución Morfológica de la Bahía de Santander; Museo Nacional de Ciancias Naturales: Madrid, Spain, 1917.

35. Díaz de Terán, J. Sedimentología y dinámica de las arenas de el puntal (Santander). Anal. Inst. Est. Ind. Econ. Ciencias Institución Cultural de Cantabria 1976, 1, 229-329.

36. Flor, G.; Flor-Blanco, G. Subsistemas estuarinos de la bahía de santander (Cantabria, norte de España). In XIII Reunión Nacional de Geomorfología. Universidad de Extremadura; Sociedad Española de Geomorfología: Cáceres, Spain, 2014; pp. 568-571.

37. MAGRAMA. Plantación de Refuerzo de las Dunas de Somo y Loredo. Available online: http: / / www.mapama.gob.es/es/costas/temas/proteccion-costa/actuaciones-proteccion-costa/cantabria/ 390489-plantacion-somo-loredo.aspx (accessed on 4 April 2018).

38. Revertido, M.; Ruiz, J.R. Ayer, Hoy y Mañana, la Modernización del Puerto de Santander, 1985-2005; Editorial del Puerto de Santander: Santander, Spain, 2006.

39. González López, J.M. Un Modelo Viscoplástico Para la Caracterización Tenso-Deformacional de Materiales Asfálticos; Universitat Politècnica de Catalunya: Catalunya, Spain, 2003.

40. Mullen, R. Manual of Photogrammetry; American Society for Photogrammetry and Remote Sensing: Rockville, MD, USA, 2004.

41. De Sanjosé-Blasco, J.J. Perfiles Dinámicos de la Bahía de Santander; Universidad de Extremadura: Extremadura, Spain, 1989.

42. De Sanjosé-Blasco, J.J.; Serrano, E.; Berenguer, F.; González-Trueba, J.; Gómez-Lende, M.; González-García, M.; Guerrero-Castro, M. Evolución histórica y actual de la línea de costa en la playa de somo (cantabria), mediante el empleo de la fotogrametría aérea y escáner láser terrestre. Cuaternario y Geomorfología 2016, 30, 119-130. [CrossRef]

43. Sanjosé, J.D.; Serrano, E.; Berenguer, F.; González-Trueba, J.J.; Gómez-Lende, M.; González-García, M.; Guerrero-Castro, M. Evolución histórica y actual de la línea de costa en las playas de somo y gerra (cantabria) mediante fotogrametría aérea y escáner láser. In En XIII Reunión Nacional de Geomorfología; Schnabel, Y.S., Gómez, A., Eds.; Universidad de Extremadura: Cáceres, Spain, 2016; Volume 30, pp. 560-563.

44. Hoffmeister, D.; Tilly, N.; Curdt, C.; Aasen, H.; Ntageretzis, K.; Hadler, H.; Willershäuser, T.; Vött, A.; Bareth, G. Terrestrial laser scanning for coastal geomorphologic research in western greece. Int. Arch. Photogramm. Remote Sens. Spat. Inf. Sci. 2012, 39, 511-516. [CrossRef]

45. Lindenbergh, R.C.; Soudarissanane, S.S.; Vries, S.D.; Gorte, B.G.H.; Schipper, M.A.D. Aeolian beach sand transport monitored by terrestrial laser scanning. Photogramm. Rec. 2011, 26, 384-399. [CrossRef]

46. González Amuchastegui, M.J.; Ibisate González de Matauco, A.; Rico Lozano, I.; Sánchez Fernández, M.; Sanjosé, J. Cambios Geomorfológicos y Gvolución de una Barra de Arena en la Desembocadura del río lea, Lekeitio-Mendexa (Bizkaia); Spanish Quaternary Research Association: Madrid, Spain, 2016. 
47. De Sanjosé-Blasco, J.J.; Serrano, E.; Berenguer, F.; González-Trueba, J.J.; Gómez-Lende, M.; González-García, M. Evolución de la línea de costa para el periodo 1988-2014 de la playa de somo (Cantabria), mediante el empleo de técnicas geomáticas. In Geo-Temas; Universitat Politècnica de Catalunya: Barcelona, Spain, 2015.

48. Badia Cebada, E. Long-Term Morphodynamic Modelling of Tidal Basins with Rivers; Universitat Politècnica de Catalunya: Catalunya, Spain, 2003. 